\title{
Architecture
}

DOI: $10.23968 / 2500-0055-2021-6-4-03-13$

\section{PRESERVING IDENTITY OF HISTORICAL ENVIRONMENTS IN SIBERIA: A CRITICAL LITERATURE REVIEW}

\author{
Daria Belova \\ Institute of Architecture and Design, Siberian Federal University \\ Svobodny St., 82, Krasnoyarsk, Russia \\ E-mail: dariia.belova@gmail.com
}

\begin{abstract}
Introduction: Currently, the projects related to the development of identical historical environments in Siberia, Russia, are predominately inconsistent. Yet there is an opportunity to find a more holistic approach to sustaining local heritage, which could address local cultures and identities through an understanding of how the location, as well as specific spatial and architectural practices, evolve. Purpose of the study: The study aimed to establish a theoretical and methodological framework for sustaining the local identity in architectural terms. Methods: According to the methodological recommendations of Groat and Wang, such methods as critical literature review and logical argumentation were used. Results: The research came to the conclusion that the city identity can be unfolded through two or more congruent layers of existence. This study deals with architectural heritage and society as two types of such layers. It suggests that the local identities of historical environments could be sustained by a combination of the following methods: 1) looking to the past, through analyzing the city's fabric and searching for "social traces" and semiotic meanings; 2) looking to the future, through using participatory design methods. This methodology should be further tested on specific historical environments in Siberia. The critical literature review will provide researchers and practitioners in the field with a fundamental theoretical framework.
\end{abstract}

\section{Keywords}

Architecture, philosophy of architecture, identity, heritage, participatory practice, sustainable development.

\section{Introduction}

Over the past century, Russia experienced two major political turning points. This, among other factors, has led to a systemic crisis of national cultural identity, including the rejection of the values of the past and fundamental cultural norms and concepts, and the erratic development of the historical architectural environment, which has been mirroring social processes. City-dwellers seem to lack any feeling of attachment to their environments, while the inconsistent development of the built environment and the resulting changes in the structure of social processes are becoming increasingly visible. International methodologies, such as, for instance, critical regionalism (Frampton, 1983), have highlighted the need to find local regional patterns and techniques with the potential to ensure the continuity of historical and cultural layers, create a sense of belonging and identity, and preserve the past in ways that guarantee cultural diversity and survivability. At the same time, the above methodology does not provide operational tools or answers on how to integrate new development projects into traditional social life. Nonetheless, there is an opportunity to develop a more holistic approach to sustaining local historical places, which would address local cultures and identities through an understanding of how the location and specific spatial practices evolve. It is currently argued in Russia that the preservation of cultural layers is one of the essential elements needed for nurturing national consciousness and a sense of national belonging (V. V. Putin). In this context, how can we enhance, or at least preserve, the complex city identity? How can we ensure the development continuity in historical environments while shaping the city identity? What issues exist within this field, what methods and tools? Thus, the purpose of this review was to explore the existing identity-oriented approaches to the sustainable development of historical architectural environments, in order to suggest a methodology or strategy that could potentially be applicable in Siberia, Russia, as well as to provide researchers and practitioners in the field with a fundamental theoretical framework.

\section{Methods}

We selected critical literature review and logical argumentation (Groat and Wang, 2013) as the primary methods of this study. The literature for the study was provided by the Scientific Libraries of the 
Siberian Federal University and the University of Cologne.

\section{Results and Discussion}

The phenomenon of identity has been investigated by a large and growing body of literature around the world (Benwell and Stokoe, 2006; Castells, 2009; Krinsky; 2004; Torabi and Brahman, 2013). For Castells, identity is "the process by which social actors build their own meaning according to cultural attributes" (Castells, 2009). Fundamentally, identity could be unfolded through the "congruity" of two or more layers of existence, or two or more interrelated phenomena: "the feeling of having a close association or connection with something" (Oxford Dictionary). Researchers today tend to decode the city identity (Bold et al. 2017; Brand, 1995) by employing the notion of heritage: "The deeper understanding of the historically contingent and embedded nature of heritage allows us to go beyond treating heritage simply as a set of problems to be solved and enables us to engage with debates about the production of identity, power and authority throughout society" (Harvey, 2001). Thus, out of a variety of components within identity, this study will focus on "heritage", understood as a "process", which, in and of itself, already encompasses many layers, along with the dimension of time. Further decomposition of the notion of identity leads to the essential social component congruent with heritage. Many researchers decode the phenomenon of heritage through tradition (which encompasses both resilience and dynamics), through inclusion, and through "knowledge transfer" and "social traces" (Araoz, 2011; Dymitrow, 2013; Hewitt and Pendlebury, 2014; Lowenthal, 1998; Pendlebury, 2013; Pendlebury and Porfyriou, 2017; Riegl, 2011; Townshend and Pendlebury, 1999). Waterton and Watson (2015) argue that today's researchers of heritage are concerned with the problems of participation, which implies construction and engagement. Smith (2007) defines heritage as a cultural process: "Heritage is a multilayered performance... that embodies acts of remembrance and commemoration while negotiating and constructing a sense of place, belonging and understanding in the present". Orbaşli (2017) adds, "Thus, conservation is increasingly becoming a process of negotiation, as the management of cultural heritage becomes based on models of consultation and participation, that are intended to give those 'affected' by a site a 'voice'". In other words, scholars define heritage as a process that encompasses communication, negotiation, engagement, assembling, meaning creation, and knowledge transfer (Smith, 2004, 2007; Smith and Waterton, 2013; Waterton and Smith, 2010). In addition, heritage is now "judged under ethical and moral criteria" (Munoz-Vinas, 2012); this concept is also enshrined in the conventions and widely published (Australia ICOMOS, 1999, 2013; Drury and McPherson, 2008; Nara, 2015).

The focus of modern science on studying complex self-developing systems significantly restructures scholarly ideals and norms, transforming the ideal of value-neutral research (Styopin et al., 1996). These transformations of the general set of scientific principles, shifting from "Objective" or "Scientific" to "Ethical", also determine the transformation of the core ideas within heritage concepts. Thus, perceiving the heritage process as a self-developing system with internal ethics and a significant social component, researchers recommend searching for the local sustainable concepts of heritage as an organic and natural part of social reality.

Several authors have noted that the focus in architectural heritage studies has shifted to such concepts as engagement, meaning, and identity, which are relatively new in theory (Waterton and Watson, 2015). Thus, researchers who gravitate to collaborative heritage as a concept claim to observe the positive effects of community engagement in the heritage process (Drury and McPherson, 2008; Yung et al., 2016). However, Pendlebury (Pendlebury et al., 2004), one of the pioneers in the field of public participation in conservation, outlines significant controversies within the recent heritage policies. Indeed, the new concept destabilizes conventional heritage discourse: "The heritage debate has continued to flex and flow since the 1980s and has gained considerable momentum over the past three decades" (Waterton and Watson, 2015). Rather than introducing certain approaches and doctrines, it has created further division and arguments. Thus, the controversies around the notions of authenticity, national identity, the power-relational values, social cohesion, etc., as well as the critique of the commodification of the above, while yielding occasional stabilizing solutions, have not yet resulted in universal wisdoms. Moreover, "heritage has become a global concern with powerful new players who are now engaged in conservation practice and research" (Orbaşli, 2017). Dragouni (2018) argues that "there is still a long way to go until we can firmly argue that community participation has been truly and fully embraced in the field... Until then, there is an imminent need for on-going critical analysis of and reflection on the topic at both theoretical and practical levels". Discourse on the subject is still "young", although it does have many undeniably significant achievements, and is worth applying to different case studies.

When it comes to the existing research, potential sub-topics, and approaches relevant to the participatory heritage process, we note that studies are broadening in scope. As Orbaşli (2017) notes, "By the end of the twentieth century, however, conservation had clearly evolved in two separate strands: conservation as an approach and 
conservation as a science". Waterton and Watson (2015) single out two perspectives within heritage research, one of which is based on approaching heritage as "operational practice" (operations management, including marketing, finance, human resources, hospitality, catering, and retailing), while the other perceives heritage as a form of "cultural practice" (sociological, cultural, social geographical and anthropological thinking). This subject is becoming more and more interdisciplinary, bringing in a wide variety of concepts (Barelkowski, 2009; Greider and Garkovich, 1994; Murzyn-Kupisz, 2013; Murzyn-Kupisz and Działek, 2013; Poulios, 2014; Stephens and Tiwari, 2015). Generally speaking, approaches have changed significantly. Research is currently: focusing attention on the largely vernacular historic cityscapes rather than on "grand, monumental" architecture; encompassing intangible components; and zooming in on local identities rather than valuing national significance. Finally, we are currently seeing a notable shift in heritage significance from "expert" evaluation to participatory evaluation.

However, the ongoing focus on democratization, human rights and social justice, control, power, decision-making, ethics, and so on remains relatively obscured in Russia. Generally, the subject of Russian heritage, let alone the heritage of Siberia, is quite poorly represented in international science, with rare exceptions (Deschepper, 2018). A review of the latest Russian academic literature has revealed the following picture. First, formal academia in Russia is strictly formalized and institutionalized, divided into disciplinary "tracks". Research dedicated to historical environments belongs to a track called "Theory and History of Architecture, Restoration and Reconstruction of Architectural Heritage", specifically the "Architecture" section, which is currently related to the "technical" field of studies. Consequently, interdisciplinary knowledge is a rare occurrence in formal Russian academia. Classical researchers of architectural heritage in Russia are usually busy with describing the past. Their studies are largely historiographic (Burdin, 2013; Merkulova and Merkulova, 2013; Meyerovich, 2016; Mishakova and Mikhaleva, 2014; Slabukha, 2016; Tsaryov, 2012), reviewing archives, dealing with notions of "typology", "styles", "method", "context", "composition", "visual integration", etc. (Dutsev, 2014; Samolkina, 2015; Stafeyev, 2015; Zaitsev, 2013), or investigating specific technical aspects. Some researchers study the semantics of traditional architecture and its elements, such as wood carving, decorative elements, etc., which, in their opinion, helps to reveal messages left behind by the societies of the past (Barabanov, 2013; Myasnikova and Volskaya, 2014; Sergeyev, 2000). Their insights have allowed for publishing extensive descriptions of the history of architecture and urban development in Russia and Siberia. Siberian researchers A. V. Slabukha and V. I. Tsaryov, who wrote major works on the development of Siberian architecture, hold a unique spot in Siberian heritage research (Slabukha, 2016; Slabukha and Sayenko, 2016; Tsaryov, 2012). However, while investigating the impact or implications of heritage and architecture, and while rethinking heritage procedures or describing heritage practice, researchers tend to miss the fact that heritage is a socially constructed phenomenon with prescribed values. The concept of Siberian heritage is therefore not explicitly formulated.

Architecture researchers in Russia make some limited effort to break the disciplinary limits, by criticizing the existing approaches to architectural heritage or proposing new ones (Aidarova, 2012; Bal'zannikova, 2014; Bolotskikh et al., 2017; Chaynikova, 2018; Devyatova, 2016; Galeev, 2017; Gumenyuk, 2012; Lepeshkina et al., 2018; Markovich and Luchkova, 2011; Okhotnikova, 2019; Orlenko, 2017; Romanova and Malevich, 2013; Selivanenko, 2015; Viktorova, 2014); or by investigating the cultural effects of specific architectural phenomena (Dayub, 2009; Lobanov, 2010; Nazarova et al., 2017; Pavlova, 2016). Some researchers discuss the aspects of how socialist monuments and heritage are perceived in a post-socialist country (Nagornaya and Petukhova, 2014; Oganesyan, 1996; Ryzhkova, 2016; Snopek, 2013). Shulgin (2004) considers heritage as a factor of socio-cultural development. Sedov (2011) gives a comprehensive overview of the perception of the architectural monuments in Russia, while Pereslegin (2015) explores the formation and development of the bodies responsible for conservation and heritage protection, as well as their interaction with society. However, researchers usually state the problem and emphasize its importance, but rarely propose comprehensive methods for socially-oriented heritage processes or present a reading of the social connotations within the historical built space. One of the rare exceptions is a study by Solovyova and Anisimova (2014), dedicated to historical environments and the tools of their development and analysis in Vologda. A unique stance is expressed by Glazychev (https://www.glazychev.ru), who comprehensively researched the phenomenon of city environments, starting to question the participatory approaches to the formation of historical environments at the end of the $20^{\text {th }}$ century. However, some Russian works from the last third of the $20^{\text {th }}$ century still defer to the official system of heritage research and practice. At the same time, "unofficial", practice-based research appears more free, dynamic, and experimental. Archnadzor (http://www. archnadzor.ru/category/wise/), "Re-school" (led by Narine Tyutcheva), MARCH architectural school, and Strelka Institute in Moscow have started to gradually change the practice.

The "social" component in environmental 
practice appeared as a theme within such tracks of Russian research as "Sociology" and "Culture Studies", which considered urban environments from their own disciplinary positions (Abysheva, 2005; Akhnayeva, 2004; Butakova and Sidorova, 2015; Chernetskaya, 1999; Chernyayeva, 2004; Donguzova, 1998; Fedorov and Ovcharova, 2012; Fedorova, 2016; Kaiser, 2010; Kogatko, 2007; Kostenko, 2004; Pomozova, 2012; Serikov, 2007; Smirnova, 2004; Soboleva, 2014; Suchorukov, 2002; Tsepelev, 2014; Zlotnitsky, 2008). Some researchers are exploring the new challenges of democracy and participation (Agapova, 2015; Donguzova, 1998; Obertas and Petukhov, 2015). One cannot overestimate the valuable contribution made by the thesis of sociologist Serikov (2007), who proposed a mechanism for managing historical centers as a complex socio-economic phenomenon, from an administrative point of view. Vilkovsky (2010) provided a comprehensive overview of the existing published theories on the sociology of architecture. However, the isolated positions of sociologists and culture studies experts appear insufficient for considering the complex heritage practice from an architectural point of view.

Thus, the subject of city identity could be elaborated on in research through understanding and analyzing the congruent layers of heritage as a process (reviewed in the temporal dimension), as well as by analyzing the heritage's social context and associated values. To summarize, various Russian researchers from different fields have tried to suggest possible changes in the approaches to Russian heritage. However, the prevailing themes are more technical, focused on the so-called "operational issues" (Waterton and Watson, 2015), while critical analysis from the cultural perspective, along with specific methods, is generally lacking, especially when it comes to regions with such unique development as Siberia. The general concept of Siberia's heritage is not formulated explicitly; the subject of possible sustainable heritage processes either has a limited presence in Russian literature or is absent from it altogether. Thus, we believe that it is necessary to research the possibility of sustainable, collaborative heritage processes in the Yenisei basin in Siberia, as the first step of a possible journey toward city identity construction.

Quite often in Russia, heritage monuments or buildings are perceived as separate entities. However, such monuments are usually part of a holistic urban fabric or environment, where all elements evoke the same feelings and have the same links with traditions, habits, and beliefs. "Places remember, and they do it through their monuments, architectural style of their buildings, inscriptions on walls, etc." (Hayden, 1995). Harrison's philosophy of "becoming", where the notions of place and life, in a broad sense, closely connect time and "living beings" into "generations of continuities in particular places" (Harrison and Rose, 2010), provides a better reading of heritage contexts. The Historic Urban Landscape (HUL) concept is an attempt to avoid the isolation of buildings, as physical objects, from their wider cultural environment, with its multi-layered history of meanings. Thus, a more "holistic" approach is needed to address the fragments of the spatial fabric in complex historical environments, which include intangible aspects and social traces.

Geographically, the number of researchers investigating the democratization of heritage is exponentially growing, encompassing representatives from different parts of the world (Amin, 2018; Murzyn-Kupisz and Działek, 2013; Paez et al., 2013; Salman et al., 2018; Yalegama et al., 2016; Yung et al., 2016). For instance, Maciuika (2014) showed differences in the approaches to reconstruction in various national and cultural contexts, according to ideological standpoints at a specific time and in a specific location. He used Asian cultures as an example: "Shinto religious tradition involves the complete reconstruction of the sacred Shinto Jingu Shrine in Ise, Japan, every 20 years". Waterton and Watson (2015) suggested that the role of nonWestern researchers and the development of local heritage discourses is significant for this mission. Geographically, Siberia is not a part of Europe or the West - but what about culturally or mentally?

When it comes to time frames, the collapse of the Soviet Union is the latest significant change that radically influenced all aspects of existence in Russia (Charley, 2010). Architecture, heritage, planning, conservation, and design are no exception. According to Slabukha (2014), since the beginning of the 1990s, work on the identification and state protection of monuments has been paused, so that in Siberia, the status of heritage has been reduced dramatically, and some monuments and memorial places have been completely lost. In addition, as Tunbridge and Ashworth (1995) explained, "The present selects an inheritance from an imagined past for current use and decides what should be passed on to an imagined future". Thus, today's heritage is widely acknowledged as an agent of assembling multiple futures. Lowenthal (2015) argued, "Every act of recognition alters survivals from the past. Simply to appreciate or protect a relic, let alone to embellish or imitate it, affects its form or our impressions. Just as selective recall skews memory and subjectivity shapes historical insight, so manipulating antiquities refashions their appearance and meaning. Interaction with a heritage continually alters its nature and context, whether by choice or by chance". Harrison (2015) perceived heritage as an ongoing act of assemblage, which occurs in the process of discussing past values, guided or conditioned by the conscious, responsible outlook to the future.

Indeed, the heritage and identity of the future 
are constructed in the present. Thus, the framework of heritage connotations from different periods, in combination with socially-inclusive methods of sense-retrieval, would widely inform the heritage process on the way to identity construction.

\section{Conclusions}

City identity can be unfolded through two or more congruent layers of existence, such as architectural heritage and society. Sustainable development of architectural heritage is a complex process (involving communication, negotiation, engagement, assemblage, meaning creation, and knowledge transfer), which expands beyond conventional heritage protection, and multiple bodies and stakeholders get involved in the journey toward sustaining the city identity. Heritage is a process that requires looking ahead and looking back at the same time. Considering the above, the human component can be integrated into the heritage process and sustained by a combination of the following methods: 1) looking to the past: analyzing the city's structures and forms, searching for social traces and semiotic meanings; 2) looking to the future: using participatory design methods. This could be achieved through an approach encompassing desk studies alongside with on-site surveys, fieldwork, and participation. This is still an emerging study subject, worth experimenting with at locations, especially in such unique regions as Siberia. Thus, all of the above can become a hypothesis to be tested out in specific Siberian environments.

This literature review has built a broad theoretical base and outlined a set of approaches that currently exist in the field. With that in mind, we aim to propose and develop research that would question the possibility of sustainable, collaborative heritage processes in Siberia, as the first step on a possible journey toward constructing the city identity. The research will propose a set of analytical tools for a preliminary design study on heritage and culminate with suggesting a methodology for establishing sustainable heritage processes and providing continuity and survivability while taking into consideration the critical evaluation given in this paper and the limitations discovered.

\section{Acknowledgments}

The author would like to thank Prof. Dr. Thiemo Breyer, Professor for Phenomenology and Anthropology at the University of Cologne, for providing support and supervision for this research, and Dr. Jo Lintonbon (The University of Sheffield), who largely influenced the study.

\section{Funding}

The paper was prepared as part of the research financed by DAAD (German Academic Exchange Service). 


\section{References}

Abysheva, Yu. Yu. (2005). The problem of shaping a city's image: the social and governance aspect. Author's Abstract of PhD Thesis in Social Sciences. Nizhny Novgorod: Lobachevsky State University of Nizhny Novgorod.

Agapova, D. (ed.) (2015). The culture of involvement: the museum as a space for dialogue and cooperation. Saint Petersburg: CEC ArtsLink, 157 p.

Aidarova, G. N. (2012). Problems and methodology of historic preservation in Kazan. News of the Kazan State University of Architecture and Engineering, No. 2 (20), pp. 9-15.

Akhnayeva, N. A. (2004). The phenomenon of St. Petersburg identity: structural and functional analysis. Author's Abstract of PhD Thesis in Social Sciences. Saint Petersburg: Saint Petersburg State University.

Amin, H. M. T. M. (2018). The impact of heritage decline on urban social life. Journal of Environmental Psychology, Vol. 55, pp. 34-47. DOI: 10.1016/j.jenvp.2017.12.002.

Araoz, G. F. (2011). Preserving heritage places under a new paradigm. Journal of Cultural Heritage Management and Sustainable Development, Vol. 1, No. 1, pp. 55-60. DOI: 10.1108/20441261111129933.

Australia ICOMOS (1999). The Burra Charter. Birwood, VIC: Australia ICOMOS, 23 p.

Australia ICOMOS (2013). The Burra Charter: The Australia ICOMOS Charter for Places of Cultural Significance. [online] Available at: http://openarchive.icomos.org/id/eprint/2145/ [Date accessed July 27, 2021].

Bal'zannikova, E. M. (2014). Preserving urban objects of historical and architectural heritage. VESTNIK MGSU (Monthly Journal on Construction and Architecture), No. 1, pp. 15-24.

Barabanov, A. A. (2013). Socio-cultural, and semantic principles of the revitalization of the industrial heritage. Eco Potential, No. 3-4, pp. 236-247.

Barelkowski, R. (2009). Involving social participation in the preservation of heritage: the experience of Greater Poland and Kujavia. WIT Transactions on Ecology and the Environment, Vol. 122, pp. 435-446.

Benwell, B. and Stokoe, E. (2006). Discourse and identity. Edinburgh: Edinburgh University Press, 328 p.

Bold, J., Larkham, P. J. and Pickard, R. (eds.) (2017). Authentic reconstruction : authenticity, architecture and the built heritage. London: Bloomsbury Academic, 352 p.

Bolotskikh, L. V., Romantsova, Ye. B. and Galtsova, O. I. (2017). The Issues of preserving architectural heritage in Russian towns. Stroitelstvo i Nedvizhimost, No. 1, pp. 61-65.

Brand, S. (1995). How buildings learn : what happens after they're built. New York: Penguin Books, 256 p.

Burdin, Ye. A. (2013). Preserving cultural heritage sites in the USSR (1917-1991). Study guide. Ulyanovsk: Ulyanovsk State Pedagogical University, $109 \mathrm{p}$.

Butakova, D. A. and Sidorova, N. V. (2015). Image of Siberian city in its residents impressions (by example of sociological survey conducted in Irkutsk). Proceedings of Irkutsk State Technical University, No. 4 (99), pp. 221-224.

Castells, M. (2009). The power of identity. The information age: economy, society, and culture. Vol. II. $2^{\text {nd }}$ edition. Malden, MA; Oxford, UK: Wiley-Blackwell, 584 p.

Charley, J. (2010). The shadow of economic history: the architecture of boom, slump and crisis. Architectural Research Quarterly, Vol. 14, Issue 4, pp. 363-372. DOI: $10.1017 /$ S1359135511000157.

Chaynikova, O. O. (2018). Special features of the process of restoration of architectural monuments - cultural symbols of power. VESTNIK MGSU (Monthly Journal on Construction and Architecture), No. 2 (113), pp. 170-189. DOI: 10.22227/1997-0935.2018.2.170-189.

Chernetskaya, A. A. (1999). Social space in daily life. Author's Abstract of PhD Thesis in Social Sciences. Saratov: State Technical University of Saratov.

Chernyayeva, T. I. (2004). The architectonics of social space. Author's Abstract of DSc Thesis in Social Sciences. Saratov: State Technical University of Saratov.

Dayub, A. V. (2009). The place of architecture in the process of social environment transformation. Author's Abstract of PhD Thesis in Philosophy. Saint Petersburg: Saint Petersburg State University.

Deschepper, J. (2018). Between future and eternity: a Soviet conception of heritage. International Journal of Heritage Studies, Vol. 25, Issue 5, pp. 491-506. DOI: 10.1080/13527258.2018.1467949.

Devyatova, Yu. A. (2016). A comprehensive approach to architectural design in historical city environments. Architecton. Proceedings of Higher Education, No. 1 (53), 5.

Donguzova, Ye. I. (1998). The sociological aspects of managing the architectural transformation of cities. Author's Abstract of PhD Thesis in Social Sciences. Ufa: Bashkir State University. 
Dragouni, M. (2018). Engaging heritage, engaging communities. International Journal of Heritage Studies, Vol. 25, Issue 3, pp. 329-332. DOI: 10.1080/13527258.2018.1493702.

Drury, P. and McPherson, A. (2008). Conservation principles, policies and guidance. London: English Heritage, 72 p.

Dutsev, M. V. (2014). The concept of artistic integration in contemporary architecture. Author's Abstract of DSc Thesis in Architecture. Nizhny Novgorod: Nizhny Novgorod State University of Architecture and Civil Engineering.

Dymitrow, M. (2013). Degraded towns in Poland as cultural heritage. International Journal of Heritage Studies, Vol. 19, Issue 7, pp. 613-631. DOI: 10.1080/13527258.2012.681681.

Fedorov, V. V. and Ovcharova, A. Zh. (2012). City phenomenon: value-semantic aspect. Bulletin of the Moscow State Region University. Series: Philosophy, No. 2, pp. 25-30.

Fedorova, O. S. (2016). The analysis of cultural, architectural and artistic factors of the city image formation. Journal of Siberian Federal University. Humanities and Social Sciences, Vol. 9, No. 8, pp. 1874-1879.

Frampton, K. (1983). Towards a critical regionalism: six points for an architecture of resistence. In: Foster, H. (ed.) The Anti-Aesthetic. Essays on Post-Modern Culture. Port Townsend, WA: Bay Press, pp. 16-30.

Galeev, S. A. (2017). Architecture and conservation of natural, cultural and spiritual heritage. The Heritage Institute Journal, No. 3 (10), 3.

Greider, T. and Garkovich, L. (1994). Landscapes: the social construction of nature and the environment. Rural Sociology, Vol. 59, Issue 1, pp. 1-24. DOI: 10.1111/j.1549-0831.1994.tb00519.x.

Groat, L. N. and Wang, D. (2013). Architectural research methods. $2^{\text {nd }}$ edition. Hoboken, NJ: John Wiley \& Sons, 468 p.

Gumenyuk, L. S. (2012). Heritage and society: history versus architecture entity. Vestnik of Saint Petersburg University. Series 6. Philosophy. Culturology. Political Science. Law. International Relations, No. 3, pp. 5-9.

Harrison, R. (2015). Beyond "natural" and "cultural" heritage: toward an ontological politics of heritage in the age of anthropocene. Heritage \& Society, Vol. 8, Issue 1, pp. 24-42. DOI: 10.1179/2159032X15Z.00000000036.

Harrison, R. and Rose, D. (2010). Intangible Heritage. In: Benton, T. (ed.) Understanding Heritage and Memory. Manchester: Manchester University Press, pp. 238-276.

Harvey, D. C. (2001). Heritage pasts and heritage presents : temporality, meaning and the scope of heritage studies. International Journal of Heritage Studies, Vol. 7, Issue 4, pp. 319-338. DOI: 10.1080/13581650120105534.

Hayden, D. (1995). The power of place : urban landscapes as public history. Cambridge, MA: London: MIT Press, 316 p.

Hewitt, L. E. and Pendlebury, J. (2014). Local associations and participation in place : change and continuity in the relationship between state and civil society in twentieth-century Britain. Planning Perspectives, Vol. 29, Issue 1, pp. 25-44. DOI: 10.1080/02665433.2013.802655.

Kaiser, N. Yu. (2010). The transformation of Russia's image in public opinion among people living in a provincial region in the Russian Federation. Author's Abstract of PhD Thesis in Philosophy. Barnaul: Altai State University.

Kogatko, D. G. (2007). Russian identity as a cultural and civilizational phenomenon. Author's Abstract of PhD Thesis in Social Sciences. Saint Petersburg: Saint Petersburg State University of Service and Economics.

Kostenko, Yu. O. (2004). Issues of managing the city's social space under conditions of contemporary society transformation: regional aspect. PhD Thesis in Sociological Studies. Ufa: Bashkir State Agrarian University.

Krinsky, C. (2004). State of the field: studies of identity in modern architecture. Anales del Instituto de Investigaciones Estéticas, Vol. 26, No. 85, pp. 31-47. DOI: 10.22201/iie.18703062e.2004.85.2182.

Lepeshkina, M. N., Dridze, D. B., Popova, Ye. A., Omelyanenko, G. B., Dubrovin, I. F., Maslova, K. N. and Kalitseva, Yu. O. (2018). Development of Eurasian cities. A review of development features. Moscow: Archsovet, $454 \mathrm{p}$.

Lobanov, A. V. (2010). Communication spaces in architecture: genesis and development trends. Author's Abstract of PhD Thesis in Architecture. Nizhny Novgorod: Nizhny Novgorod State University of Architecture and Civil Engineering.

Lowenthal, D. (1998). The heritage crusade and the spoils of history. Cambridge: Cambridge University Press, 358 p.

Lowenthal, D. (2015). The past is a foreign country - revisited. Cambridge: Cambridge University Press, 680 p.

Maciuika, J. V. (2014). The historic preservation fallacy? Transnational culture, urban identity, and monumental architecture in Berlin and Dresden. In: Diefendorf, J.M. and Ward, J. (eds.) Transnationalism and the German City. Studies in European Culture and History. New York: Palgrave Macmillan, pp. 239-260. DOI: 10.1057/9781137390172_15.

Markovich, O. B. and Luchkova, V. I. (2011). Adaptive using of architecture monuments. In: New Ideas of New Century: Proceedings of the International Scientific Conference at Pacific National University, Vol. 1, pp. 391-396.

Merkulova, M. Ye. and Merkulova, M. M. (2013). Wooden buildings in Krasnoyarsk in the $19^{\text {th }}$ and early $20^{\text {th }}$ century. Krasnoyarsk: Siberian Federal University, 140 p. 
Meyerovich, M. G. (2016). From garden cities to social cities: the main architectural and urban planning concepts in the USSR (1917 - first half of the 1930s). Author's Abstract of DSc Thesis in Architecture. Nizhny Novgorod: Nizhny Novgorod State University of Architecture and Civil Engineering.

Mishakova, O. E. and Mikhaleva, K. A. (2014). From history of development of museological thought of architecture monuments as objects of cultural heritage. Austrian Journal of Humanities and Social Sciences, No. 9-10, pp. 27-31.

Munoz-Vinas, S. (2012). Contemporary theory of conservation. London: Routledge, 239 p.

Murzyn-Kupisz, M. (2013). The socio-economic impact of built heritage projects conducted by private investors. Journal of Cultural Heritage, Vol. 14, Issue 2, pp. 156-162. DOI: 10.1016/j.culher.2012.04.009.

Murzyn-Kupisz, M. and Działek, J. (2013). Cultural heritage in building and enhancing social capital. Journal of Cultural Heritage Management and Sustainable Development, Vol. 3, Issue 1, pp. 35-54. DOI: 10.1108/20441261311317392.

Nagornaya, M. S. and Petukhova, E. I. (2014). Architecture sotsgorod as heritage: European experience and Russian prospects. Management in Modern Systems, No. 4 (4), pp. 16-26.

Nara (2015). Nara + 20: On heritage practices, cultural values, and the concept of authenticity. Heritage \& Society, Vol. 8, Issue 2, pp. 144-147. DOI: 10.1080/2159032X.2015.1126115.

Nazarova, M. P., Barkovskaya, A. Yu. and Nikitina, D. V. (2017). Palace of Culture as social and cultural centerpiece of a typical Soviet city (the case of the Palace of Culture named after Yu. A. Gagarin, Volgograd). Vestnik Volgogradskogo Gosudarstvennogo Arhitekturno-Stroitel'nogo Universiteta. Seriya: Stroitel'stvo i Arhitektura, No. 50 (69), pp. 401-411.

Obertas, O. G. and Petukhov, V. V. (2015). Architectural aspects of identity of Vladivostok as European city in the Pacific Region. Fundamental Research, No. 11, Part 7, pp. 1352-1357.

Oganesyan, M. G. (1996). Modernization of the residential areas built in the 1920s-1930s and their protection as urban planning monuments. PhD Thesis in Architecture.Yerevan: Yerevan Institute of Architecture and Construction.

Orbaşli, A. (2017). Conservation theory in the twenty-first century: slow evolution or a paradigm shift? Journal of Architectural Conservation, Vol. 23, Issue 3, pp. 157-170. DOI: 10.1080/13556207.2017.1368187.

Orlenko, N.I. (2017). Problems of protection, restoration, and modern adaptation of architectural monuments. In: Research, Education, and Experimental Design. Abstracts of Presentations at the International Research and Practice Conference, Vol. 1. Moscow: Moscow Architectural Institute, pp. 133-134.

Paez, D., Basabe, N. and Gonzalez, J. L. (2013). Social processes and collective memory: a cross-cultural approach to remembering political events. In: Pennebaker, J. W., Paez, D. and Rime, B. (eds.) Collective Memory of Political Events. New Jersey: Psychology Press, pp. 159-186.

Pavlova, M. (2016). International experience of architectural heritage preservation and implementation in urban life. Archyort, No. 2, pp. 16-24.

Pendlebury, J. (2013). Conservation values, the authorised heritage discourse and the conservation-planning assemblage. International Journal of Heritage Studies, Vol. 19, Issue 7, pp. 709-727. DOI: 10.1080/13527258.2012.700282.

Pendlebury, J. and Porfyriou, H. (2017). Heritage, urban regeneration and place-making. Journal of Urban Design, Vol. 22, Issue 4, pp. 429-432. DOI: 10.1080/13574809.2017.1326712.

Pendlebury, J., Townshend, T. and Gilroy, R. (2004). The conservation of English cultural built heritage: a force for social inclusion? International Journal of Heritage Studies, Vol. 10, Issue 1, pp. 11-31. DOI: 10.1080/1352725032000194222.

Pereslegin, N. V. (2015). History of the formation and development of architectural heritage protection bodies in Moscow in the context of their interaction with society in the Soviet period. PhD Thesis in Architecture. Moscow: Moscow Institute of Architecture (State Academy).

Pomozova, N. B. (2012). Symbols as a tool for shaping civic identity: a comparative analysis of Russia and China. Author's Abstract of PhD Thesis in Philosophy. Moscow: MGIMO University.

Poulios, I. (2014). Discussing strategy in heritage conservation: Living heritage approach as an example of strategic innovation. Journal of Cultural Heritage Management and Sustainable Development, Vol. 4, Issue 1, pp. 16-34. DOI: 10.1108/JCHMSD-10-2012-0048.

Riegl, A. (1903). Der Moderne Denkmalkultus: Sein Wesen Und Seine Entstehung. Vienna: Zentral-Kommission Für Kunst-Und Historische Denkmale, 65 p.

Romanova, L. S. and Malevich, S. S. (2013). Adaptation of historical buildings to modern conditions. Experience of Tomsk Restoration School. Vestnik Tomskogo gosudarstvennogo arkhitekturno-stroitel'nogo universiteta. Journal of Construction and Architecture, No. 4 (41), pp. 115-126.

Ryzhkova, T. S. (2016). Features of perception and evaluation of architectural monuments of socialist period in the Federal Republic of Germany. National Association of Scientists, No. 10 (26), pp. 5-6.

Salman, M., Malik, S., Tariq, F. and Khilat, F. (2018). Conservation analysis of Gali Surjan Singh: a study of architectural and social aspects. Journal of Architectural Conservation, Vol. 24, Issue 2, pp. 134-151. DOI: 10.1080/13556207.2018.1488203. 
Samolkina, Ye. G. (2015). Specifics of the newest wooden architecture in Russia. PhD Thesis in Architecture. Nizhny Novgorod: Nizhny Novgorod State University of Architecture and Civil Engineering.

Sedov, V. V. (2011). Architectural monuments in Russia: national perception of antiquity. [online] Available at: http://arheologpskov.ru/index.php/nasledie/37-pamyatnik-arkhitektury-v-rossii-osobennosti-natsionalnogo-vospriyatiya-drevnosti [Date accessed January 22, 2020].

Selivanenko, A. M. (2015). "Cultural tourism" as one of the forms of preservation of architectural and historical monuments. The Scientific Opinion, No. 8, pp. 182-185.

Sergeyev, A. A. (2000). Semiotic interpretation of the creative concepts of Russian architecture. PhD Thesis in Architecture. Yekaterinburg: Ural State Academy of Architecture and Art.

Serikov, A. A. (2007). Development of the historical center of a large city as a focus of social design. Author's Abstract of DSc Thesis in Social Sciences. Nizhny Novgorod: Volgo-Vyatskaya Academy of Public Service.

Shulgin, P. M. (2004). Historical and cultural heritage as a special regional resource and socio-economic development factor. Universe of Russia. Sociology. Ethnology, Vol. 13, No. 2, pp. 115-133.

Slabukha, A. V. (2014). Questions of history of studying and preservation architectural heritage in Siberia round the Yenisei River. Proceedings of the $2^{\text {nd }}$ International Research and Practical Conference "Modern Issues in Architecture, Urban Planning, and Design”. Krasnoyarsk: Siberian Federal University. [online] Available at: http://conf.sfu-kras.ru/ city2014/participant/12655 [Date accessed March 20, 2020].

Slabukha, A. V. (2016). Determining the historical and cultural value of architectural heritage sites (Part 2): criteria and method in modern expert praxis. Man and Culture, No. 6, pp. 9-22. DOI: 10.7256/2409-8744.2016.6.20767.

Slabukha, A. V. and Sayenko, I. A. (2016). The Problems of Revealing, Studying, Reconstruction and Restoration of Architectural Heritage of Siberia. Krasnoyarsk: Siberian Federal University, 35 p.

Smith, L. (2004). Archaeological theory and the politics of cultural heritage. London: Routledge, $272 \mathrm{p}$.

Smith, L. (2007). Uses of heritage. London: Routledge, 368 p.

Smith, L. and Waterton, E. (2013). Heritage, communities and archaeology. London: Bloomsbury, 144 p.

Snopek, K. (2013). Beliaevo Forever. Moscow: Strelka Press, 59 p.

Smirnova, N. A. (2004). Regional identity in the context of contemporary Russian society. PhD Thesis in Sociological Studies. Volgograd: Volgograd State University.

Soboleva, K. V. (2014). Visual strategies of social identification in a contemporary Russian city (as exemplified by St. Petersburg). Author's Abstract of PhD thesis in Social Sciences. Saint Petersburg: Herzen State Pedagogical University.

Solovyova, D. N. and Anisimova, L. V. (2014). Adaptive design techniques in the historical environment as a way to preserve the unique character of cities. In: Volkova, T. F. (ed.) Theory and Practice of Environment Design: Proceedings of the $6^{\text {th }}$ International Research and Practice Conference. Penza: Penza State University of Architecture and Construction, pp. 69-72.

Stafeyev, I. S. (2015). Accounting for the urban planning role during the restoration of architectural memorials. In: Balzannikov, M. I., Galitskov, K. S., Akhmedova, Ye. A. (eds.) Traditions and Innovations in Civil Engineering and Architecture. Urban Planning. Collection of Articles. Samara: Samara State University of Architecture and Civil Engineering, pp. 206-209.

Stephens, J. and Tiwari, R. (2015). Symbolic estates: community identity and empowerment through heritage. International Journal of Heritage Studies, Vol. 21, Issue 1, pp. 99-114. DOI: 10.1080/13527258.2014.914964.

Styopin, V. S., Gorokhov, V. G. and Rozov, M. A. (1996). Philosophy of science and technology. Moscow: Gardarika, 400 p. Torabi, Z. and Brahman, S. (2013). Effective factors in shaping the identity of architecture. Middle-East Journal of Scientific Research, Vol. 15, Issue 1, pp. 106-113. DOI: 10.5829/idosi.mejsr.2013.15.1.2357.

Townshend, T. and Pendlebury, J. (1999). Public participation in the conservation of historic areas: case-studies from North-East England. Journal of Urban Design, Vol. 4, Issue 3, pp. 313-331. DOI: 10.1080/13574809908724453.

Tsaryov, V. I. (2012). History of urban development in Siberia. Krasnoyarsk: Siberian Federal University, 12 p.

Tsepelev, A. Yu. (2014). Social modeling of regional identification: the sociological and managerial aspect. PhD Thesis in Sociological Studies. Moscow: Institute of Sociology of the Russian Academy of Sciences.

Tunbridge, J. E. and Ashworth, G. J. (1995). Dissonant heritage : the management of the past as a resource in conflict. Chichester; New York: John Wiley, 299 p.

Viktorova, L. A. (2014). The process of preservation of monuments of architecture. Save or ruin? Architecture and Construction of Russia, No. 10, pp. 24-31.

Vilkovsky, M. (2010). Sociology of architecture. Moscow: Russian Avant-Garde Foundation, 592 p. 
Waterton, E. and Smith, L. (2010). The recognition and misrecognition of community heritage. International Journal of Heritage Studies, Vol. 16, Issue 1-2, pp. 4-15. DOI: 10.1080/13527250903441671.

Waterton, E. and Watson, S. (2015). The Palgrave Handbook of Contemporary Heritage Research. London: Palgrave Macmillan, 586 p. DOI: https://doi.org/10.1057/9781137293565.

Yalegama, S., Chileshe, N. and Ma, T. (2016). Critical success factors for community-driven development projects: a Sri Lankan community perspective. International Journal of Project Management, Vol. 34, Issue 4, pp. 643-659. DOI: 10.1016/j.ijproman.2016.02.006.

Yung, E. H. K., Lai, L. W. C. and Yu, P. L. H. (2016). Public decision making for heritage conservation: a Hong Kong empirical study. Habitat International, Vol. 53, pp. 312-319. DOI: 10.1016/j.habitatint.2015.12.004.

Zaitsev, A. (2013). Contextualism as a stillistic movement in arhitecture in the end of the $20^{\text {th }}$ - beginning of the $21^{\text {st }}$ century. PhD Thesis in Architecture. Nizhny Novgorod: Nizhny Novgorod State University of Architecture and Civil Engineering.

Zlotnitsky, Ye. E. (2008). Social mechanism of managing the brand of a region. PhD Thesis in Sociological Studies. Moscow: State University of Management. 


\title{
СОХРАНЕНИЕ ИДЕНТИЧНОСТИ ИСТОРИЧЕСКОЙ СРЕДЫ В СИБИРИ: КРИТИЧЕСКИЙ ОБЗОР ЛИТЕРАТУРЫ
}

\author{
Дарья Александровна Белова \\ Институт архитектуры и дизайна, Сибирский федеральный университет \\ пр. Свободный, 82, Красноярск, Россия \\ E-mail: dariia.belova@gmail.com
}

\begin{abstract}
Аннотация
В настоящее время проекты, связанные с развитием уникальной исторической среды в Сибири, в основном, противоречивы. Тем не менее, есть возможность найти более целостный подход к сохранению местного наследия, который мог бы учитывать местные культуры и самобытность через понимание того, как развивается историческая среда, а также через конкретные пространственные и архитектурные практики. Цель исследования: Создать теоретическую и методологическую основу для поддержания местной идентичности с архитектурной точки зрения. Методы: В соответствии с методологическими рекомендациями Грота и Вана использовались такие методы, как критический анализ литературы и логическая аргументация. Результаты: Было обнаружено, что понятие «городская идентичность» может раскрываться через два или более конгруэнтных «слоя». В данном исследовании рассматриваются архитектурное наследие и общество как два из возможных «слоев». Предположительно, локальная идентичность исторической среды может быть сохранена в процессе неразрушающего развития с помощью сочетания следующих методов: 1) обращение к прошлому посредством анализа структуры города и поиска "социальных следов" и семиотических значений; 2) взгляд в будущее с использованием методов соучаствующего проектирования. Было решено протестировать методологию на конкретных исторических условиях Сибири. Приведённый критический обзор литературы предоставит исследователям и практикам в данной области базовую теоретическую основу.
\end{abstract}

\section{Ключевые слова}

Архитектура, философия архитектуры, идентичность, наследие, партисипация, устойчивое развитие. 